\title{
Long-Term Implications of Post-ACA Health Reform on State Health Care Policy
}

\author{
Patrick N. O'Mahen, PhD. ${ }^{1,2}$ (1) and Laura A. Petersen, MD MPH', \\ ${ }^{1}$ Center for Innovations in Quality, Effectiveness and Safety (IQuESt), Michael E. DeBakey VA Medical Center, Houston, TX, USA; ${ }^{2}$ Section of Health \\ Services Research, Department of Medicine, Baylor College of Medicine, Houston, TX, USA.
}

In the midst of the COVID-19 outbreak, health care reform has again taken a major role in the 2020 election, with Democrats weighing Medicare for All against extensions of the Affordable Care Act, while Republicans quietly seem to favor proposals that would eliminate much of the ACA and cut Medicaid. Although states play a major role in health care funding and administration, public and scholarly debates over these proposals have generally not addressed the potential disruption that reform proposals might create for the current state role in health care. We examine how potential reforms influence statefederal relations, and how outside factors like partisanship and exogenous shocks like the COVID-19 pandemic interact with underlying preferences of each level of government. All else equal, reforms that expand the ACA within its current framework would provide the least disruption for current arrangements and allow for smoother transitions for providers and patients, rather than the more radical restructuring proposed by Medicare for All or the cuts embodied in Republican plans.

$\mathrm{J}$ Gen Intern Med 36(3):775-8

DOI: $10.1007 / \mathrm{s} 11606-020-06168-4$

(c) Society of General Internal Medicine (This is a U.S. government work and not under copyright protection in the U.S.; foreign copyright protection may apply) 2020

B efore the COVID-19 pandemic, health policy debates in the US presidential election had focused on the proper role that private insurance plans in the US health system. Leftwing candidates for the Democratic nomination backed versions of Medicare for All, a new federal single-payer plan that would eventually eliminate most private insurance. In contrast, more moderate Democrats promoted strengthening the Affordable Care Act's framework, which both expands existing public programs and subsidizes uninsured individuals purchasing regulated private plans.

But debates over private versus public insurance neglect enduring divisions within the public sector. State and federal governments share responsibility for US public insurance

Received April 7, 2020

Accepted August 14, 2020

Published online September 8, 2020 programs. This division of power dates prior to Medicare and Medicaid's 1965 passage and has been renegotiated when reforms have filtered through American health care. Current proposals would add to this history, but like past reform efforts, both parties' plans risk foundering on state elected officials' two primary policy priorities: maximal federal funding and minimal federal restrictions on spending it. ${ }^{1}$

We review state roles in administering Medicaid and the ACA's insurance exchanges, and explore how proposed reforms may alter the federal-state balance of power. We also examine how disruptive and contested those changes are likely to be. Finally, we discuss how factors like partisanship and exogeneous shocks alter underlying federal-state dynamics.

\section{CURRENT STATE ROLES}

States wield substantive health policymaking power through individual insurance markets, Medicaid, and the Children's Health Insurance Program (CHIP). Medicaid and CHIP alone covered 71.6 million Americans at the end of the first quarter of $2019,{ }^{2}$ while state-regulated ACA individual exchanges covered 13.7 million. $^{3}$

States have latitude to develop Medicaid programs - including forgoing the program, though joining unlocks federal matching grants. Programs must cover core groups and services. However, states control important aspects of program design, such as whether to offer optional services or cover certain populations. ${ }^{4}$ Programs range from fee-forservice reimbursement run by states to managed care administered by commercial insurers. ${ }^{5}$

The ACA's Medicaid expansion gives states the option to insure all adults under the $138 \%$ of poverty line. The federal government covers more than 90 percent of the cost of the expansion group, which is more generous than the 50 to 83 percent match provided for other Medicaid-eligible groups. ACA-embedded administrative changes also require states to streamline administration, imposing new federal mandates to improve beneficiary service. ${ }^{1}$

States can negotiate further flexibility into their Medicaid programs. Section 1115 of the Social Security Act allows the federal government to waive part of the law to enable states to implement alternative provisions, so long as they match the core 
goals of Medicaid. ${ }^{6}$ Most recently, some states have considered work requirements. ${ }^{7}$

The ACA also added new aspects to federal-state interplay by creating national standards for individual insurance markets. It mandated minimum benefits packages, banned exclusions for pre-existing health conditions, standardized actuarial value in a four-tier plan structure (bronze, silver, gold, platinum) and offered a universal subsidy system to help low- and middle-income households buy insurance. ${ }^{8}$

However, new federal standards have come with more federal resources for states through premium subsidies and grants to set up exchanges. Additionally, the ACA also allows states to have significant administrative flexibility. ${ }^{9}$ States can choose to develop their own exchanges or default to Healthcare.gov. They can merely certify exchange plans that meet federal requirements or embrace an active-purchaser model. They choose whether to fund enhanced outreach services to drive enrollment, ${ }^{10}$ or supplement federal premium subsidies with state money to increase plan affordability. ${ }^{11}$

States can even jettison the exchanges altogether. Section 1332 of the ACA allows states to take ACA federal funds and create their own programs, if they maintain coverage and quality standards. ${ }^{12}$

Although partisan control and ideology influence how states wield these powers to produce policy, states do have unified interests against the federal government. For example, prior to the ACA, governors across the ideological spectrum resisted federal mandates to extend Medicaid coverage to the elderly and disabled. ${ }^{1}$ Similarly, several states-from conservative Utah to liberal Massachusetts-have sought federal permission to partially expand Medicaid to $100 \%$ of the federal poverty line instead of the ACA's mandated $138 \%$. The reason is that states want individuals with incomes 100 to $138 \%$ of the poverty line to purchase insurance on the exchanges - which are funded entirely by the federal government, unlike Medicaid, which requires state contributions. ${ }^{13}$ The federal government under both the Obama and Trump administrations have opposed proposals that give states access to $90 \%$ federal matching grants for partial expansions, which negates state fiscal advantages of a partial expansion. ${ }^{14}$

These federal-state power struggles have consequences for providers and patients. The resolution of the partial Medicaid expansion debate above, for example, determines whether large patient groups have coverage through Medicaid or exchange plans, which have different structures for premiums, co-pays, covered services, and in-network providers. Providers serving those patients would face changes in reimbursement rates and coverage mixes for their patient pools as well.

\section{POTENTIAL REFORM EFFECTS ON STATE POWER}

Broadly, Democrats in Congress or who ran for president have embraced one or more of three basic reform approaches: strengthening the current framework of the ACA, introducing a public insurance buy-in option, or developing a Medicare for All plan. ${ }^{15}$ Republicans back granting additional autonomy to states and reducing federal health funding.

Democratic plans building within ACA frameworks represent relatively modest changes to the state-federal status quo. Common reforms in these plans include expanding exchange premium subsidies through removing the income cap on subsidies (currently $400 \%$ of the household poverty line), lowering expected contributions for those currently eligible for subsidies, and pegging subsidy levels to higher-level plans (gold instead of silver). ${ }^{16-18}$

This approach keeps Medicaid intact and requires minimal state regulatory changes. More federal funding for exchange subsidies would increase federal dollars flowing into a state's economy, but not directly impact state budgets.

Adding public insurance options to the exchanges for individuals currently ineligible for Medicare and Medicaid could have varied effects on state-federal responsibilities. ${ }^{15}$ Some buy-in options include letting individuals over a certain age buy into existing Medicare, ${ }^{19,20}$ or create a federal public option administered through Medicare open to individuals on the exchanges. ${ }^{15}$ These proposals would likely also have modest impact on the state-federal balance of power, though they would cover more individuals through federally managed programs and potentially displace the Medicaid expansion in non-expansion states. Medicaid-for-all options, which open state Medicaid programs to anyone wishing to buy into the program, ${ }^{21-23}$ would alter the balance by giving states the power to create unique Medicaid plans sold on the exchanges. States would gain considerable policy autonomy ${ }^{22}$ and directly take in federal exchange subsidies as revenue. Nevertheless, states could also face increased expenditures uncovered by federal dollars if they underpriced their plans. ${ }^{23}$

At the aggressive end of proposals, "Medicare for all" approaches ${ }^{24}$ - even ones retaining employer insurance - would drastically alter the balance of state and federal power and financing in health care. These proposals roll state Medicaid programs into a universal federal program, removing states' ability to regulate individual insurance markets.

How proposals deal with current state-provided Medicaid funding has enormous ramifications for state-level budgeting, policymaking, and politics. ${ }^{25}$ Plans that do not require maintenance-of-effort funding would provide states with budget windfalls that could be reallocated to other priorities.

But commandeering states' Medicaid contributions, necessary to limit new federal outlays, would draw vehement opposition from governors and state legislators across the ideological spectrum, as it reduces state power without providing budget relief. Navigating how to levy assessments on states that had not expanded Medicaid would exacerbate resistance.

After failing to repeal the ACA in 2017, Republicans have put off proposing specific health reform plans. ${ }^{26}$ However, limited GOP developments seem to build on a 2017 proposal from Sens. Lindsey Graham (R-SC) and Bill Cassidy (R-LA). ${ }^{27}$ GrahamCassidy would repeal ACA insurance subsidies and Medicaid 
expansion while redistributing ACA funding to states as block grants. This would permit states' flexibility at a price: In addition to capping block grants by a set formula, the proposal replaces Medicaid's open-ended grants with hard per capita limits that would increase more slowly than projected health costs. This offloads federal costs onto states and would force states to cut services or increase taxes.

\section{OUTSIDE FACTORS INTERACT WITH STATE-FEDERAL DYNAMICS}

The contest over autonomy and resources between federal and state governments does not exist in a vacuum. Instead, it interacts with other factors to influence state preferences.

Partisan control of state governments plays a primary role in whether states embrace or resist major changes to federal health policy, as experience with ACA implementation shows. Republican-controlled states have been less likely to embrace Medicaid expansion and set up insurance exchanges than their Democratic-controlled counterparts. ${ }^{28-31}$

In federal-level reform plans, state ideological preferences interact with state desires for autonomy. In 2017, Republicans designed Graham-Cassidy plan's grants to temporarily raise federal funding for Republican-controlled states that blocked Medicaid expansion. They paid for this with more drastic cuts to states that had fully implemented the ACA's coverage expansions. ${ }^{32}$ In this way, Republican federal lawmakers sought to win buy-in for their plan among states run by Republican co-partisans by giving them both autonomy and increased federal resources.

Additionally, Republican reform plans generally biased the waiver process in favor of states that want to enact their partisan-preferred reforms. For example, the proposal allowed states to request to opt-out of the ACA's mandates that insurers must cover standard "essential" benefits. Combined with budget cuts, the easiest changes to make would be to implement coverage reductions in line with those favored by conservative ideologues. ${ }^{33}$ This process, which bureaucracy scholars call "deck-stacking,",34 slants state autonomy toward enacting certain partisan preferences.

In contrast to Republicans who have proposed redistributing resources away from states controlled by partisans who favor a strong welfare state, some Democratic proposals alter who controls resources within a state. Democratic presidential nominee Joe Biden has campaigned on a public option plan that provides a no-premium public option to lowincome recipients in states without expanded Medicaid. ${ }^{20}$ The result is that states retain some control over federal money only if they expand Medicaid; otherwise, a federally controlled program will cover the same individuals. The ACA state exchanges function similarly, with states that declined to develop their own insurance exchanges losing some control over policy implementation (and one-time setup grants) to the federal government.

Like Republicans, Democrats attempt to slant state regulatory autonomy toward party goals. The ACA, for example, allows states to expand health coverage through Basic Health Plans instead of insurance exchanges, ${ }^{35}$ or use Section 1332 waivers to design changes to their health systems, provided they cover at least as many people as ACA policies would. ${ }^{12}$

Second, state preferences and the federal-state balance of power are subject to external shocks altering the underlying policy environment. Increased demands on the health system and economic collapse wrought by the COVID-19 pandemic, for example, have strained state health resources. Within weeks of the start of the initial US spread, the federal government agreed to fund a greater share of state Medicaid programs for the pandemic's duration in return for states giving up autonomy to cut eligibility. ${ }^{36}$ Sweeping federal reform proposals may well meet less embedded resistance from states in a different underlying environment.

\section{STATE SUPPORT AND REFORM PATHWAYS}

Reformers must address how proposals affect the current federal-state split of health care policymaking responsibility to build a political coalition that can pass a given reform, as well as understand the practical requirements to smoothly implement it. Proposed reforms all affect the policy powers and resources that states command and will have knock-on effects for doctors, hospitals, and patients.

The most aggressive single-payer proposals from the 2020 primary campaign would likely strip states of policymaking power without lowering state outlays, while Republican plans would curtail federal funding in exchange for limited increases to policy autonomy. Proposals to expand insurance coverage through mechanisms contained within current programs may offer the easiest path for implementation and friendly federalstate relations. However, other powerful forces can and do interact with states' desire for more power and autonomy, further complicating the already complex federal-state dynamics that run through US health care.

Corresponding Author: Laura A. Petersen, MD MPH; Center for Innovations in Quality, Effectiveness and Safety (IGuESt), Michael E. DeBakey VA Medical Center, Houston, TX, USA (e-mail: laurap@bcm. edu).

Funding This material is based on work supported by the Department of Veterans Affairs, Veterans Health Administration Office of Research and Development, through the Center for Innovations in Quality, Effectiveness and Safety (CIN 13-413).2

\section{Compliance with Ethical Standards:}

Conflict of Interest: The authors declare that they do not have a conflict of interest. 
Disclaimer: The views expressed in this article are those of the authors and do not necessarily represent those of the Veterans Health Administration or the US Government.

\section{REFERENCES}

1. Rose S. Financing Medicaid: Federalism and the Growth of America's Health Care Safety Net. Ann Arbor: University of Michigan Press; 2013.

2. Centers for Medicare and Medicaid Services. Medicaid and CHIP Enrollment Data. https://www.medicaid.gov/medicaid/national-medicaid-chip-program-information/medicaid-chip-enrollment-data/monthlymedicaid-chip-application-eligibility-determination-and-enrollment-reports-data/index.html. Published 2020. Accessed 25 June 2020.

3. Fehr R, Cox C, Levitt L. Changes in Enrollment in the Individual Health Insurance Market through Early 2019; 2019. https://www.kff.org/ private-insurance/issue-brief/data-note-changes-in-enrollment-in-theindividual-health-insurance-market-through-early-2019/. Accessed January 23, 2020.

4. Centers for Medicare and Medicaid Services. Mandatory and Optional Medicaid Benefits. https://www.medicaid.gov/medicaid/benefits/mandatory-optional-medicaid-benefits/index.html. Accessed 1 June 2020.

5. Hinton E, Rudowitz R, Diaz M, Singer N. Ten Things to Know About Managed Care; 2019. https://www.kff.org/medicaid/issue-brief/10things-to-know-about-medicaid-managed-care/.

6. The Henry J. Kaiser Family Foundation. Medicaid Waiver Tracker: Approved and Pending Section 1115 Waivers by State. https://www.kff. org/report-section/section-1115-waiver-tracker-definitions/. Published 2020. Accessed July 11, 2020.

7. O'Mahen PN, Petersen LA. State governments and judges may moderate the impact of the Trump administration's promotion of Medicaid work requirements. J Gen Intern Med. 2019;34(9):1899-1902. https://doi. org/10.1007/s11606-019-04846-6.

8. McDonough JE. Inside National Health Reform. Los Angeles: University of California Press; 2011.

9. Anderson D. Managing marketplaces requires state regulators to make tough choices. Health Serv Res. 2019. https://doi.org/10.1111/14756773.13189

10. Shafer PR, Fowler EF, Baum L, Gollust SE. Television advertising and health insurance marketplace consumer engagement in Kentucky: A natural experiment. J Med Internet Res. 2018. https://doi.org/10.2196/ 10872.

11. Quinn M. California take Obamacare to a New Level as the Law's Fate Looms. Governing. https://www.governing.com/topics/health-humanservices/gov-california-newsom-obamacare-subsidies-mandate.html. Published July 11, 2019.

12. Wright B, Porter A, Singer PM, Jones DK. The devolution of health Reform? A comparative analysis of state innovation waiver activity. J Health Polit Policy Law. 2018. https://doi.org/10.1215/036168787277404.

13. McIntyre A, Joseph AM, Bagley N. Small change, big consequences Partial medicaid expansions under the ACA. N Engl J Med. 2017;377:1004-1006. https://doi.org/10.1056/NEJMp1710265.

14. Center on Budget and Policy Priorities. Frequently Asked Questions about "Partial" Medicaid Expansion. https://www.cbpp.org/sites/default/files/atoms/files/4-10-19health-faq1.pdf. Published 2019 Accessed 11 July 2020.

15. Kliff S, Scott D. We read 9 Democratic plans for expanding health care Here's how they work. Vox. https://www.vox.com/2018/12/13/ $18103087 /$ medicare-for-all-explained-single-payer-health-care-sandersjayapal. Published June 6, 2019.

16. H.R.1425 - Patient Protection and Affordable Care Enhancement Act. 2020. https://www.congress.gov/bill/116th-congress/house-bill/1425/ text.

17. Astor M, Friedman L, Goldstein D, Kanno-Youngs Z, Sangor-Katz $\mathbf{M}$ Tankersley J. 6 Takeaways From the Biden-Sanders Joint Task Force Proposals. New York Times. https://www.nytimes.com/2020/07/09/ us/politics/biden-sanders-task-force.html\#link-42d793b5. Published July 9, 2020
18. Epstein R, Goodnough A. Joe Biden, Echoing Obama, Pledges to Shore Up the Affordable Care Act. New York Times. https://www.nytimes.com/ 2019/07/15/us/politics/biden-health-care.html. Published July 15, 2019.

19. Kliff S. Medicare at 50: Sen. Debbie Stabenow explains her Medicare buy-in plan. Vox. https://www.vox.com/2019/2/13/18220704/medicare-buy-in-universal-coverage-stabenow. Published 2019. Accessed July $12,2020$.

20. Biden-Sanders Unity Task Force Recommendations; 2020. https:// joebiden.com/wp-content/uploads/2020/07/UNITY-TASK-FORCERECOMMENDATIONS.pdf. Accessed July 12, 2020

21. Ollove M. Medicaid "Buy-In" Could Be a New Option for the Uninsured. Pew Stateline. https://www.pewtrusts.org/en/research-and-analysis/ blogs/stateline/2019/01/10/medicaid-buy-in-could-be-a-new-healthcare-option-for-the-uninsured. Published January 10, 2019.

22. Anderson D, Sandoe E. A Framework For Evaluating Medicaid Buy-In Proposals. Health Affairs Blog.

23. Holahan $\mathbf{J}$, Blumberg LJ. The Implications of a Medicaid Buy-In Proposal; 2018. https://www.urban.org/sites/default/files/publication/95961/2001672_medicaid_buy_in_2018.pdf.

24. Johnson M, Kishore S, Berwick DM. Medicare For All: An Analysis of Key Policy Issues. Health Aff. 2020;39(1):133-141. https://doi.org/10. 1377/hlthaff.2019.01040.

25. Frakt AB, Oberlander J. Challenges To Medicare For All Remain Daunting. Health Aff. 2020;39(1):142-145.https://doi.org/10.1377/ hlthaff.2019.01494.

26. Armour S, Peterson K. GOP Puts Off Unveiling New Health Plan Until After 2020 Election. Wall Street Journal. https://www.wsj.com/articles/ trump-sees-no-vote-on-gop-health-plan-until-after-2020-election11554212678. Published April 2, 2019.

27. Chen LJ. Getting Ready for Health Reform 2020: Republican Options.https://www.commonwealthfund.org/publications/journal-article/2018/nov/getting-ready-health-reform-2020-republican-options. Published November 16, 2018.

28. O'Mahen P, Petersen L. State-Level Political Institutions Matter: The Balance of Powers Among Governors, Legislatures, and Direct Democracy Influences Medicaid Expansion Decisions. World Med Heal Policy. 2020. https://doi.org/10.1002/wmh3.329.

29. Rocco P, Haeder SF. How intense policy demanders shape postreform politics: Evidence from the Affordable Care Act. J Health Polit Policy Law. 2018;43(2):271-305. https://doi.org/10.1215/03616878-4303498.

30. Hertel-Fernandez A, Skocpol T, Lynch D. Report on Health Reform Implementation: Business Association, Conservation Networks, and the Ongoing Republican War over Medicaid Expansions. J Heal Polit Policy, Law. 2016;41(2):239-286. https://doi.org/10.1215/03616878-3476141.

31. Barrilleaux $\mathbf{C}$, Rainey $\mathbf{C}$. The politics of need: Examining governors' decisions to oppose the "obamacare" medicaid expansion. State Polit Policy Q. 2014;14(4):437-460. https://doi.org/10.1177/ 1532440014561644

32. Zernike K, Abelson R, Goodnough A. New Effort to Kill Obamacare Is Called 'the Most Radical.' New York Times. https://www.nytimes.com/ 2017/09/21/health/graham-cassidy-obamacare-repeal-.html. Published September 21, 2017.

33. Aron-Dine A. Cassidy-Graham's Waiver Authority Would Gut Protections for People with Pre-Existing Conditions; 2017. https://www.cbpp.org/ blog/cassidy-grahams-waiver-authority-would-gut-protections-for-people-with-pre-existing-conditions. Accessed 3 Aug 2020.

34. Mccubbins MD, Noll RG, Weinggast BR. Administrative Procedures as Instruments of Political Control. J Law Econ Organ. 1987;3:243-277.

35. Centers for Medicare and Medicaid Services. Basic Health Program. https://www.medicaid.gov/basic-health-program/index.html. Accessed 3 July 2018

36. Centers for Medicare and Medicaid Services. Families First Coronavirus Response Act - Increased FMAP FAQs. https://www.medicaid.gov/stateresource-center/downloads/covid-19-section-6008-faqs.pdf. Published 2020. Accessed April 24, 2020.

Publisher's Note: Springer Nature remains neutral with regard to jurisdictional claims in published maps and institutional affiliations. 